\title{
Stunting of Onion in the Columbia Basin of Oregon and Washington Caused by Rhizoctonia spp.
}

L. J. Patzek, Department of Crop and Soil Sciences, and L. J. du Toit, Department of Plant Pathology, Washington State University Northwestern Washington Research \& Extension Center, Mount Vernon 98273-4768; T. C. Paulitz, United States Department of Agriculture-Agricultural Research Service, Root Disease and Biological Control Research Unit, Washington State University, Pullman 99164-6430; and S. S. Jones, Department of Crop and Soil Sciences, Washington State University Northwestern Washington Research \& Extension Center, Mount Vernon 98273-4768

\begin{abstract}
Patzek, L. J., du Toit, L. J., Paulitz, T. C., and Jones, S. S. 2013. Stunting of onion in the Columbia Basin of Oregon and Washington caused by Rhizoctonia spp. Plant Dis. 97:1626-1635.

During 2009 and 2010, 45 isolates of Rhizoctonia spp. were recovered from onion bulb crops in the semiarid Columbia Basin of Oregon and Washington, in which patches of severely stunted onion plants developed following rotation with winter cereal cover crops. Characterization of isolates recovered from naturally infested soil and roots was performed by sequence analysis of the ribosomal DNA (rDNA) internal transcribed spacer region, with the majority of isolates (64\%) identified as Rhizoctonia solani. In steam-pasteurized field soil, stunting of onion was caused by isolates of $R$. solani anastamosis groups (AGs) $2-1,3,4$, and 8 , as well as Waitea circinata var. circinata and binucleate Rhizoctonia AG E evaluated at 13 and 8 or 15 and $15^{\circ} \mathrm{C}$ day and

night temperatures, respectively, typical of spring planting conditions in the Columbia Basin. Isolates of $R$. solani AG 5 as well as binucleate AG A and I were nonpathogenic. The most virulent isolates belonged to $\mathrm{AG}$ 8, although an $\mathrm{AG} 3$ and an $\mathrm{AG} \mathrm{E}$ isolate were also highly virulent. Isolates of AG 2-1 and 3 caused moderate levels of disease, while isolates of AG 4 and W. circinata var. circinata caused low levels of disease. Emergence was reduced by isolates of AG 2-1, 3, and E. When the various AGs were grown at temperatures of 5 to $30^{\circ} \mathrm{C}$, the relative growth rate of the Rhizoctonia isolates was not positively correlated with virulence on onion within an AG.
\end{abstract}

In 2012, approximately 3.3 million t of onion (Allium cepa) bulbs were harvested from 60,000 ha in the United States, with an estimated farmgate value of $\$ 944$ million (49). Oregon and Washington produced $39 \%$ of the national onion crop on 18,600 ha, yielding an estimated farmgate value of $\$ 300$ million (49). Dry bulb onion crops in the semiarid Columbia Basin of Oregon and Washington are commonly grown in 3- to 4-year rotations with cereals, pea (Pisum sativum), potato (Solanum tuberosum), sweet corn (Zea mays), carrot (Daucus carota), and other crops (36). Onion crops are planted primarily from late February to mid-April, mostly by direct-seeding, when average daily air temperatures are 8 to $15^{\circ} \mathrm{C}$.

Over the past decade, stunting of onion caused by Rhizoctonia spp. has become an increasing problem in irrigated onion crops planted in the Columbia Basin. The genus Rhizoctonia, belonging to the class Basidiomycota, is a complex of filamentous fungal species that are plant parasitic, saprotrophic, soilborne, entirely hyphal, and mostly asexual (32). The taxonomy of the genus continues to evolve nearly two centuries after its establishment (15), especially with the advent of molecular techniques. At present, between 30 and 50 epithets are believed to exist (1). Perhaps most fundamentally, the Rhizoctonia complex is separated into two forms based on the number of nuclei per hyphal cell (32). The multinucleate species have three or more nuclei per cell, and a teleomorph genus of either Thanatephorus Donk or Waitea Warcup and Talbot. Rhizoctonia solani Kühn belongs to the first genus while $R$. oryzae and $R$. zeae belong to the latter. The binucleate Rhizoctonia spp. have predominantly two nuclei per cell and a teleomorph genus of Ceratobasidium Rogers containing about 15

Corresponding author: L. J. du Toit, E-mail: dutoit@wsu.edu

Accepted for publication 1 July 2013.

http://dx.doi.org/10.1094/PDIS-04-13-0385-RE

(C) 2013 The American Phytopathological Society species $(20,21,29)$. Furthermore, subspecific grouping of the Rhizoctonia spp. has been attempted using a number of methods $(2,24,32,48)$ but the anastomosis group (AG) system, based on hyphal anastomosis reactions, has been the most widely adopted for $R$. solani and binucleate Rhizoctonia spp. (9). The subgroups can have different host specificities and vary in pathogenicity depending on the soil environment. At present, there are 14 AGs (AG-1 through AG-13 and AG-BI) described for $R$. solani $(10,14)$, and 7 AGs (CAG-1 to CAG-7) described in the United States and 19 (AG-A to AG-S) in Japan for binucleate Rhizoctonia spp. $(8,20,21,29)$.

Stunting of onion in the Columbia Basin occurs when the crops are planted in combination with winter cereal cover crops (16), and a similar problem has been diagnosed recently in Australia (52). In the Columbia Basin onion production systems, the cover crops provide a wind barrier in the spring to protect emerging onion seedlings against wind- and sandblasting on the sandy soils typical of this region. Cereal cover crops typically are seeded in fall, either in strips or broadcast. If the cover crop is broadcast, then onion seed is planted in the spring into beds formed after incorporation of the cover crops in strips, with the remaining strips of the cover crop left standing between the onion beds to protect the onion seedlings. If the cover crop is planted in strips in the fall, onion seed is planted between the strips in the spring. Once the cover crop has reached a growth stage that provides adequate wind protection, it is killed selectively with a herbicide. Herbicide application can occur before, coincident with, or after onion seeding, depending on growth stage of the cover crop. The dead, upright foliage of the cover crop serves as a physical barrier for wind- and sandblasting until after the onion plants are beyond the seedling stage of susceptibility to infection by Rhizoctonia spp.

Beginning in May to mid-June, depending on the onion seeding date, infection of onion seedlings by Rhizoctonia spp. becomes identifiable as circular or irregular patches of stunted onion plants in the field $(16,17)$. Patches can range from $<1 \mathrm{~m}$ to $>10 \mathrm{~m}$ in diameter. The patches may extend along the direction of the rows, and the greatest degree of stunting typically is observed in onion 
rows immediately adjacent to the cover crop rows that have been killed with herbicide. Severely impacted fields can have 10 to $15 \%$ of the total crop area stunted. Onion cultivars do not appear to differ greatly in yield response to the disease (43), although extensive evaluation of onion germplasm remains to be done.

$R$. solani AG 8, the causal agent of Rhizoctonia root rot of cereal crops in Oregon and Washington $(27,34,35,37,44,51)$, was hypothesized as the causal agent of onion stunting for several reasons. The occurrence of damage in distinct patches is a commonality between onion stunting and Rhizoctonia root rot in grain crops, the latter also known as bare patch (37). Onion fields lacking cereal cover crop or green manure crop residues in the rooting zone of developing onion seedlings do not appear to be affected by the disease. This suggests that infested cover crop residues are a primary source of inoculum leading to infections of onion crops under the semiarid conditions of this region. Onion seedlings are only impacted by the disease between 1 and 6 weeks after emergence, which is consistent with $R$. solani generally being pathogenic only to juvenile plant tissues $(32,50)$. Suggestive of cereal root rot symptoms, the root systems of onion seedlings typically develop a "spear-tipping" effect, remain short and sparse, and may display a light-brown discoloration without distinct lesions $(16,40)$.

Previous studies have demonstrated that infections on onion can be initiated successfully by isolates of $R$. solani AGs 1, 2-1, 3, 4, 5, and $8(19,22,23,46,52,54)$; binucleate Rhizoctonia spp. AGs A, Ba, $\mathrm{Bi}, \mathrm{E}, \mathrm{F}, \mathrm{G}, \mathrm{K}, \mathrm{O}$, and R $(8,18,19,22,23)$; as well as Waitea circinata var. zeae $(R$. zeae) $(18,22)$. Wicks et al. (52) frequently collected isolates of AG 2-1, AG 3, and AG 8 from stunted onion plants in the "Mallee" region of South Australia. They found that isolates of $R$. solani AG 2-1 and AG 8 consistently caused severe stunting in onion seedlings grown in infested soils. However, only quantification of the DNA of AG 8 correlated significantly with stunted patches in the field. This led to the conclusion that onion stunting in South Australia was primarily associated with isolates of AG 8, though interactions with other pathogens also may have been involved.

Because little is known about the etiology of this disease in the Columbia Basin of Washington and Oregon, the objectives of this study were to (i) identify the Rhizoctonia spp. and AGs inhabiting soils and plants in stunted patches of onion bulb crops in the Columbia Basin, (ii) investigate the effect of inoculum density of isolates of each of these Rhizoctonia spp. and AGs on the severity of stunting, and (iii) study the growth characteristics of these Rhizoctonia spp. on an agar medium at different air temperatures.

\section{Materials and Methods}

Identification of Rhizoctonia isolates. Isolates of Rhizoctonia spp. were recovered from three commercial onion fields in Morrow County, OR. In each 40- to 50-ha field irrigated by center pivot, patches of severely stunted plants were observed during spring 2009 and 2010. This is a major irrigated vegetable-growing area in the semiarid Columbia Basin, and the third most productive agricultural county in Oregon by 2011 gross farm sales (49). Naturally infested soils within and outside patches of stunted plants were baited using the toothpick method (33). Isolations were also made from the roots of onion plants, as well as potato and pea plants growing as volunteers in the same fields. For toothpick baiting, each soil sample was placed in a plastic pot, watered until completely saturated, and incubated at $16^{\circ} \mathrm{C}$. After $48 \mathrm{~h}$, five flat, white birch wooden toothpicks (Diamond Brands) were inserted into the soil at an even spacing to a depth of $5 \mathrm{~cm}$. After another $48 \mathrm{~h}$, the five toothpicks were removed, gently tapped clean of soil, and placed on $2 \%$ water agar. For root isolations, seedlings were washed gently in sterilized distilled water and blotted dry, and then sections of the roots and basal plates were plated onto water agar. The morphology of mycelia growing on the water agar plates was examined with a dissecting microscope (Olympus SZ, $\times 10$ to $\times 40$ magnification) after 12 to $48 \mathrm{~h}$. A hyphal tip was excised from each mycelium identified putatively as Rhizoctonia and placed on a plate of potato dextrose agar (PDA) medium (Difco). If a PDA culture was free of contaminating organisms, a second culture was prepared on a PDA slant and archived in a laboratory collection at $4^{\circ} \mathrm{C}$. In preparation for DNA isolation, each initial isolation was cultured for up to 7 days in $15 \mathrm{ml}$ of potato dextrose broth (PDB) (Difco) in a petri dish (100 $\mathrm{mm}$ in diameter by $15 \mathrm{~mm}$ deep) at $25^{\circ} \mathrm{C}$. The mycelial mat of each isolate was then washed three times in sterilized distilled water and blotted dry on a sterilized Whatman No. 1 filter disk. The mycelium was then stored at $-20^{\circ} \mathrm{C}$ in 1.5-ml Eppendorf tubes.

Total DNA was obtained from mycelia using the FastDNA kit (QBIOgene) and FastPrep FP120 homogenizer (QBIOgene) according to the manufacturer's protocol. The DNA template for sequencing included the internal transcribed spacer 1 (ITS1) + $5.8 \mathrm{~S}+$ ITS2 ribosomal DNA (rDNA) regions amplified with the universal eukaryotic primers UN-UP18S42 (5'-CGTAACAAGGTT TCCGTAGGTGAAC-3') and UN-LO28S576B (5'-GTTTCTTTT CCTCCGCTTATTAATATG-3') $(5,38,39)$. Polymerase chain reactions (PCRs) consisted of $2 \mu \mathrm{l}$ of DNA template, $6 \mu \mathrm{l}$ of $5 \times$ buffer, $1.5 \mathrm{mM} \mathrm{MgCl} 2,0.2 \mathrm{mM}$ each deoxynucleotide, $10 \mathrm{pmol}$ of each primer, and $1.25 \mathrm{U}$ of Taq polymerase (Promega Corp.) in a total volume of $30 \mu \mathrm{l}$. The PCR assay was performed with a PTC-200 thermocycler (MJ Research) using the following program: $94^{\circ} \mathrm{C}$ for $3 \mathrm{~min}(1 \mathrm{cycle}) ; 92^{\circ} \mathrm{C}$ for $45 \mathrm{~s}, 60^{\circ} \mathrm{C}$ for $45 \mathrm{~s}$, and $72^{\circ} \mathrm{C}$ for $60 \mathrm{~s}$ ( 31 cycles); $72^{\circ} \mathrm{C}$ for $10 \mathrm{~min}\left(1\right.$ cycle); and then held at $4^{\circ} \mathrm{C}$. Agarose gel electrophoresis was used to verify PCR amplification before continuing with the sequencing procedure.

Unconsumed nucleotides and salts were removed from the PCR product mixture using ExoSAP-IT (USB Corporation) according to the manufacturer's protocol. The resultant ExoSAP-IT product was used for sequencing reactions, each set up using a 10- $\mu$ l total volume consisting of $4 \mu \mathrm{l}$ of ABI PRISM BigDye Terminator Cycle Sequencing Ready Reaction kit (Applied Biosystems), 4 pmol of forward primer (described above), and $5 \mu$ of ExoSAP-IT product. DNA amplification was performed with the following program: 2 $\min$ at $94^{\circ} \mathrm{C}(1 \mathrm{cycle})$; and $2 \mathrm{~min}$ at $94^{\circ} \mathrm{C}, 1 \mathrm{~min}$ at $50^{\circ} \mathrm{C}$, and 1.5 min at $60^{\circ} \mathrm{C}$ ( 24 cycles). Sequencing reactions were cleaned of dye terminators, dNTPs, and other low molecular weight materials using Performa DTR Gel Filtration Cartridges (EdgeBio) according to the manufacturer's protocol. This final product was dried in a DNA speed-vac concentrator and run on a 3730 DNA Analyzer (Applied Biosystems). One complete sequence was obtained for each region of the ITS1-5.8S-ITS2 sequence, and stretches of junk sequence at the ends were deleted using CLC Sequence Viewer (version 6; CLC Bio). The sequences were queried against the National Center for Biotechnology Information sequence database using the online BLAST tool. Only sequence homologies of 98 to $100 \%$ were considered in assigning a species, subgroup, and AG to each isolate. All isolates are deposited with the United States Department of Agriculture-Agricultural Research Service Root Disease and Biological Control Research Unit in Pullman, WA.

Inoculum preparation. A modification of the protocol developed by Paulitz and Schroeder (33) was used in the preparation of inoculum of the appropriate Rhizoctonia isolates. Briefly, $800 \mathrm{ml}$ of whole oat kernels (Avena sativa) was mixed with $800 \mathrm{ml}$ of distilled water in a 3.78-liter high-density polyethylene jug, and sealed with an autoclaveable foam plug and aluminum foil. The jug and contents were autoclaved twice for $90 \mathrm{~min}$, once on each of two consecutive days. The sterilized oat kernels were then infested with 5-mmdiameter, colonized agar plugs taken from a 1-week-old PDA culture of the appropriate Rhizoctonia isolate (30 agar plugs/jug). Jugs were incubated in the dark at $25^{\circ} \mathrm{C}$ for 6 weeks, and the contents were shaken once per week to facilitate complete colonization of the oat kernels. The inoculum was air dried on kraft paper, ground in a coffee grinder, and sieved to obtain particle sizes of 250 to $1,000 \mu \mathrm{m}$. Inoculum for each isolate was stored in plastic zip-lock bags at $4^{\circ} \mathrm{C}$ in the dark until quantification and use (no longer than 6 months). Inoculum density was quantified by dilution plating on $2 \%$ water agar. Colonies were counted every $12 \mathrm{~h}$ for 3 days.

Influence of inoculum density of Rhizoctonia spp. on onion seedling disease severity. A disease assay was conducted using 
one isolate of each Rhizoctonia taxon obtained from the Columbia Basin. The purpose was to determine the influence of inoculum density on onion disease severity caused by each of the following nine Rhizoctonia isolates: $R$. solani AG 2-1 (isolate Rh060811), AG 3 (Rh060801), AG 4 (Rh010901), AG 5 (Rh070930), and AG 8 (Rh070927); binucleate Rhizoctonia AG A (Rh010913), AG E (Rh070923), and AG I (Rh070914); and W. circinata var. circinata (Rh070924). All pathogenicity studies were performed in Sagehill series soil originating from uncultivated portions of an onion bulb farm in Morrow County. This soil is a very fine sandy loam, consisting of 52 to $69 \%$ sand and 0.5 to $1.4 \%$ organic matter in the rooting zone. Before infestation with the appropriate Rhizoctonia isolate, the soil was steam pasteurized for $1 \mathrm{~h}$ at $60^{\circ} \mathrm{C}$, air dried on kraft paper, and sieved to a particle size of $2 \mathrm{~mm}$. Steam-pasteurized field soil was infested with each Rhizoctonia isolate at seven inoculum concentrations: 0, 2.5, 4.0, 20.0, 100.0, 250.0, and 500.0 $\mathrm{CFU} / \mathrm{g}$ of soil. About $70 \mathrm{~g}$ of infested soil was placed into each cone-shaped tube (cone-tainer) $(16 \mathrm{~cm}$ long, $2.5-\mathrm{cm}$ inside diameter, and 66-ml volume; Stuewe and Sons, Inc.) and moistened with $30 \mathrm{ml}$ of water. One onion seed ('Talon'; Bejo Zaden B.V.) was placed on the soil surface of each tube and covered with $16 \mathrm{~g}$ of noninfested, pasteurized soil. Cone-tainers were arranged in a completely randomized design (CRD) in plastic trays. The cone-tainers were then covered with clear polyethylene plastic until plant emergence to maintain a high level of relative humidity. Plants were grown in a greenhouse for a total of 6 weeks at temperatures of 15 and $15^{\circ} \mathrm{C}$ day and night, respectively, and a 12-h photoperiod to mimic cool spring conditions during onion seeding in the Columbia Basin. Plants were watered 2 days after emergence and then at 2- to 3-day intervals to maintain a cone-tainer weight within $5 \%$ of the initial weight. Six weeks after planting, onion seedlings were harvested by cutting open the cone-tainers and gently washing the soil from the roots under running tap water. Plants were maintained on moistened paper towels until plant observations could be completed on the same day. The following dependent variables were measured with a metal ruler: plant shoot height, rooting depth, and total root length (all in centimeters). Plants were dried in paper bags at $60^{\circ} \mathrm{C}$ for $72 \mathrm{~h}$, and the dry plant biomass (milligrams) was recorded.

Influence of inoculum density and isolate of Rhizoctonia spp. on onion seedling disease severity. The purpose of the second set of inoculum density experiments was to test multiple isolates (where available) of each Rhizoctonia sp. and AG found to be pathogenic to onion in the preceding study, using slightly cooler $\left(13\right.$ and $8^{\circ} \mathrm{C}$ ) day and night temperatures. Steam-pasteurized field soil was infested separately with each of the following Rhizoctonia isolates: R. solani AG 2-1 (Rh060811, Rh070913, and Rh070937), AG 3 (Rh060801, Rh070933, and Rh070942), AG 4 (Rh010901, Rh070909, and Rh070929), AG 8 (Rh070927, Rh070922, and Rh070943), and binucleate Rhizoctonia AG E (Rh070923) at each of eight concentrations: $0,4,8,16,32,64,128$, and $256 \mathrm{CFU} / \mathrm{g}$ of soil. The experimental conditions were identical to those described above except that plants were grown for a total of 8 weeks under a 12-h photoperiod at $13^{\circ} \mathrm{C}$ by day and $8^{\circ} \mathrm{C}$ by night in a Percival PGC-20ALB plant growth chamber (Percival Scientific, Inc.). Plants were fertilized three times over the course of the trial with 20-20-20 NPK + micronutrients (JR Peters, Inc.) dissolved in water. Onion shoot height, rooting depth, total root length, and dry plant biomass were recorded as described for the preceding inoculum density trials.

Growth of Rhizoctonia isolates on agar at different temperatures. To understand the potential for Rhizoctonia spp. to cause disease in onion fields during spring conditions, an investigation of the influence of temperature on colony growth rate of those $R h i$ zoctonia spp. determined to be pathogenic to onion (refer to experiments described previously) was completed. Temperatures can fluctuate widely from February to April in the Columbia Basin, when a majority of the onion bulb crops are planted. Averaged over a 30-year period (1979 to 2009), monthly mean minimum air temperatures in Hermiston, OR were $-2,1$, and $4^{\circ} \mathrm{C}$ in February,
March, and April, respectively, while the monthly mean maximum temperatures were 9,15 , and $19^{\circ} \mathrm{C}(28)$. This study included 10 isolates of the following Rhizoctonia spp.: $R$. solani AG 3 (Rh060801, Rh070933, Rh070942), R. solani AG 4 (Rh010901, Rh070909, Rh070929), R. solani AG 8 (Rh070922, Rh070927, Rh070943), and binucleate Rhizoctonia AG E (Rh070923). The isolates were transferred onto 1/5-strength PDA in 60-by-15-mm sterilized polystyrene petri dishes using a 4-mm-diameter mycelial disk of each isolate taken from the margin of a 5-day-old PDA culture. Each dish was sealed with Parafilm (Structure Probe, Inc.) and incubated in the dark at $5,10,15,20,25,30$, or $35^{\circ} \mathrm{C}$, with four replicate plates/isolate/temperature. Colony diameter (millimeters) was measured $12,24,36,48,60,72,84$, and $96 \mathrm{~h}$ after inoculation along two perpendicular lines intersecting at the center of the colony.

Data analyses. Studies of the effects of inoculum density and isolate of Rhizoctonia on disease severity each entailed a CRD with either 9 or 10 replicate plants per treatment. Each study was carried out twice. The dependent variable responses were normalized to a percentage of the control treatment $(0 \mathrm{CFU} / \mathrm{g}$ of soil) and the data were analyzed for interactions and mean separations as a mixed-effects model using the PROC MIXED procedure with the default restricted maximum likelihood (REML) method of estimation in SAS (version 9.2; SAS Institute).

Disease progress curves were fit to either a linear or a nonlinear four-parameter sigmoidal model (4) using SigmaPlot 11.0 (Systat Software Inc.). The four-parameter sigmoidal function was

$$
Y=\operatorname{Min}+(\operatorname{Max}-\operatorname{Min}) /\left[1+10^{\left(\log E D_{50}-X\right) *_{n_{H}}}\right]
$$

where $Y=$ the response normalized based on the control treatment at a $\log$-transformed inoculum density, $X$ and $\log E D_{50}$ represent the log-transformed inoculum density at the point of inflection of the sigmoid curve, $\operatorname{Min}=$ the lowest observed response, $\operatorname{Max}=$ the highest observed response, and $n_{H}=$ a Hillslope. The effective inoculum dose (ED) which yielded $50 \%$ of the maximum modeled response $\left(E_{50}\right)$ was provided as a coefficient in the sigmoidal model, while the $\mathrm{ED}_{90}$ was derived algebraically from the model. The effect of inoculum density and Rhizoctonia spp. on the emergence of onion seedlings was assessed by four-parameter, sigmoidal regression analysis on mean emergence data normalized for the control treatment and plotted against log-transformed inoculum densities. There were no degrees of freedom available for the statistical analysis of percent emergence for each treatment combination (isolate-inoculum density). Therefore, means were determined by combining percent emergence responses from the two repeats of the experiment and three isolates for each $R$. solani AG evaluated.

The coefficient of determination $\left(R^{2}\right)$ and the bias-corrected $R^{2}$ $\left(R^{2}\right.$ adj $)$ are inappropriate for demonstrating the performance or validity of nonlinear models, including four-parameter, sigmoidal models (45), and, therefore, were omitted from all analyses. Instead, the $P$ value derived from the analysis of variance (ANOVA) $F$ test was used as a measure of the validity of model fit. A significant regression was required to model $\mathrm{ED}_{50}$ and $\mathrm{ED}_{90}$ estimates as well as maximum reductions in response variables as a percent of the noninoculated control treatment.

The study of growth of Rhizoctonia isolates on agar at different temperatures was treated as a one-way ANOVA, and the experiment was carried out twice. The data were analyzed as a mixedeffects model using the PROC MIXED procedure with the REML method of estimation in SAS. The main effect of experiment and the treatment-experiment interactions were not significant; thus, results from the two experiments were combined for analysis to improve the statistical power of the test.

\section{Results}

Characterization of Columbia Basin Rhizoctonia isolates by rDNA ITS sequence analysis. Forty-five isolates of Rhizoctonia spp. were recovered and assigned to a species, subgroup, and AG based on 98 to $100 \%$ rDNA ITS sequence homologies with GenBank accessions (Table 1). In all, 11 unique Rhizoctonia genotypes 
were identified, including $R$. solani AGs 2-1, 3, 4, 5, 8, and 9; binucleate Rhizoctonia AG A, E, and I; as well as $W$. circinata var. circinata and var. zeae. The most dominant species were AG 4 (18\% of isolates), AG 8 (16\%), and AG 3 (13\%). Three isolates were identified as binucleate Rhizoctonia spp. but a further subgroup designation could not be assigned. Three other isolates were identified as Rhizoctonia spp. but no further designation could be assigned.

In all, $44 \%$ of the isolates were recovered directly from the roots of onion plants growing within stunted patches. These isolates represented a relatively wide range of groups: $R$. solani AG 2-1, 3, 4, and 8 as well as binucleate Rhizoctonia AG A, W. circinata var. circinata, and W. circinata var. zeae. Of the isolates recovered, $31 \%$ were recovered directly from the roots of pea plants and $13 \%$ from the roots of potato plants growing as volunteers in onion bulb crops. The remaining five isolates were baited from soil samples. Soil sampled from patches of stunted onion plants yielded one isolate each of $R$. solani AG 8,W. circinata var. circinata, and an unknown species of Rhizoctonia. One isolate each of binucleate Rhizoctonia AG E and W. circinata var. circinata were baited from soil sampled from asymptomatic portions of the onion crops.

Influence of inoculum density of Rhizoctonia spp. on onion seedling disease severity. For the initial study of the effect of inoculum density on disease severity caused by one isolate of each representative Rhizoctonia spp. and AG on onion seedlings, the four-parameter sigmoidal model accurately described $92 \%$ of the relationships between response variables normalized based on the control treatment. Isolates of $R$. solani AGs 2-1, 3, 4, and 8 as well as binucleate Rhizoctonia AG E were pathogenic on onion (Table 2). Reductions in onion plant weight and height were 25 to $42 \%$

Table 1. Rhizoctonia isolates obtained from three commercial onion fields in Morrow County, OR in 2009 and 2010 , including Rhizoctonia solani, binucleate Rhizoctonia spp., Waitea circinata, and unidentified Rhizoctonia spp.

\begin{tabular}{|c|c|c|c|c|}
\hline Species, AG, subgroup ${ }^{a}$ & Isolate & Source $^{b}$ & Location $^{c}$ & Accession $^{d}$ \\
\hline \multicolumn{5}{|l|}{ Rhizoctonia solani } \\
\hline AG 2-1 & Rh060811 & Pea & Stunted & FM867592; EU591804 \\
\hline AG 2-1 & Rh070913 & Pea & Stunted & DQ355130; AB054853 \\
\hline AG 2-1 & Rh070937 & Onion & Stunted & DQ355130; FJ435129 \\
\hline AG 3 & Rh060801 & Pea & Stunted & $\mathrm{AB} 000024$ \\
\hline AG 3 & Rh070912 & Pea & Stunted & AB019020; AY387569 \\
\hline AG 3 & Rh070933 & Potato & Asymptomatic & AB000041; AY387526 \\
\hline AG 3 & Rh070934 & Potato & Asymptomatic & AB019020; AY387528 \\
\hline AG 3 & Rh070935 & Potato & Asymptomatic & AY387528.1; AB019010 \\
\hline AG 3 & Rh070942 & Onion & Stunted & AB000024; GQ885147 \\
\hline AG 4 & Rh010901 & Onion & Stunted & FJ746956; EU591803 \\
\hline AG 4 & Rh070908 & Pea & Stunted & EU591803; EU591801 \\
\hline AG 4 & Rh070909 & Pea & Stunted & EU591803; EU591801 \\
\hline AG 4 & Rh070910 & Pea & Stunted & EU591809; HQ629872 \\
\hline AG 4 & Rh070915 & Pea & Stunted & EU591755; EU591759 \\
\hline AG 4 & Rh070929 & Onion & Stunted & EU591803; EU591801 \\
\hline AG 4 & Rh070939 & Onion & Stunted & AF354074; AF153776 \\
\hline AG 4 & Rh070940 & Onion & Stunted & FJ435140; FM867594 \\
\hline AG 5 & Rh070930 & Potato & Stunted & DQ355140; AF354113 \\
\hline AG 5 & Rh070931 & Potato & Stunted & DQ355140; EU591752 \\
\hline AG 5 & Rh070932 & Potato & Stunted & DQ355140; AF354112 \\
\hline AG 8 & Rh060828 & Onion & Stunted & AF354067; AF354068 \\
\hline AG 8 & Rh070918 & Onion & Stunted & AF354067; AF153797 \\
\hline AG 8 & Rh070919 & Onion & Stunted & DQ356413; AF354067 \\
\hline AG 8 & Rh070922 & Soil & Stunted & AF354068; AF354067 \\
\hline AG 8 & Rh070927 & Onion & Stunted & DQ356413; AF153798 \\
\hline AG 8 & Rh070941 & Onion & Stunted & DQ356413; AF354067 \\
\hline AG 8 & Rh070943 & Pea & Stunted & DQ356413; AF354067 \\
\hline AG 9 & Rh070921 & Pea & Stunted & AY154315; AB000037 \\
\hline AG 9 & Rh070938 & Pea & Stunted & AY154315; AB000046 \\
\hline \multicolumn{5}{|c|}{ Binucleate Rhizoctonia spp. } \\
\hline $\mathrm{AG} \mathrm{A}$ & Rh010907 & Onion & Stunted & AJ242900; AY927356 \\
\hline AG A & Rh010913 & Onion & Stunted & AJ242900; AY927356 \\
\hline AG A & Rh090801 & Onion & Stunted & AJ242900; EU591764 \\
\hline AG E & Rh070923 & Soil & Asymptomatic & DQ279013; AB290018 \\
\hline AG I & Rh070914 & Pea & Stunted & DQ356409; DQ356407 \\
\hline$\ldots$ & Rh010905 & Onion & Stunted & DQ356407; AJ242882 \\
\hline$\ldots$ & Rh070911 & Pea & Stunted & .. \\
\hline$\ldots$ & Rh090108 & Onion & Stunted & DQ356407; EU645602 \\
\hline \multicolumn{5}{|l|}{ Waitea circinata } \\
\hline var. circinata & Rh010909 & Onion & Stunted & EU693449; DQ356414 \\
\hline var. circinata & Rh070924 & Soil & Stunted & EU693448; FJ755858 \\
\hline var. circinata & Rh070925 & Soil & Asymptomatic & EU693449; DQ356414 \\
\hline var. circinata & Rh070936 & Onion & Stunted & EU693449; GQ521107 \\
\hline var. zeae & Rh060815 & Onion & Stunted & EU591763; DQ356414 \\
\hline \multicolumn{5}{|c|}{ Unidentified Rhizoctonia spp. } \\
\hline a & Rh010915 & Onion & Stunted & DQ421232; AF407006 \\
\hline$\ldots$ & Rh070920 & Pea & Stunted & .. \\
\hline$\ldots$ & Rh070926 & Soil & Stunted & $\ldots$ \\
\hline
\end{tabular}

a $\mathrm{AG}=$ anastamosis group.

b Isolates baited from naturally infested onion soils, or cultured from the roots of onion, pea, and potato plants growing in onion fields (latter two species as volunteers).

c Soil and roots collected for fungal isolations originated from either patches of stunted onion plants or asymptomatic areas of onion fields.

${ }^{\mathrm{d}}$ GenBank accessions with 98 to $100 \%$ ribosomal DNA internal transcribed spacer sequence homologies with that of field isolates were used to assign species, AG, and subgroup. 
for the AG 2-1 isolate, 28 to $57 \%$ for the AG 3 isolate, 29 to $53 \%$ for the AG 4 isolate, 28 to $44 \%$ for the AG 8 isolate, and 31 to $53 \%$ for the binucleate Rhizoctonia AG E isolate. The W. circinata var. circinata isolate consistently reduced plant weight and rooting depth, although the reductions were relatively small (21 to $24 \%$ of that of the noninoculated control plants), and the disease response was observed only at the two greatest inoculum densities, 250 and $500 \mathrm{CFU} / \mathrm{g}$ of soil. The $R$. solani AG 5 isolate caused stunting in only one repeat of the experiment and only at the greatest inoculum densities. Isolates of binucleate Rhizoctonia AG A and I were nonpathogenic on onion.

Of the five isolates which were consistently pathogenic in both experiments, only $R$. solani AG 8 achieved maximal disease response at relatively low inoculum densities; $\mathrm{ED}_{50}$ estimates were 2.4 to $10.4 \mathrm{CFU} / \mathrm{g}$ of soil and $\mathrm{ED}_{90}$ estimates were 3.3 to 17.6 $\mathrm{CFU} / \mathrm{g}$ of soil for all response variables. Therefore, a low inoculum concentration could induce a 34 to $44 \%$ reduction in seedling biomass. The AG 2-1 isolate reduced growth at relatively low inoculum densities, while $\mathrm{ED}_{50}$ estimates were greatest for the $\mathrm{AG} 3,4$, and $\mathrm{E}$ isolates. Considering virulence as a gradient, with the most virulent isolate being that which caused the greatest reduction in plant growth and had the lowest $\mathrm{ED}_{50}$ estimate, the $R$. solani $\mathrm{AG} 8$ isolate was highly virulent on onion, whereas the AG 2-1 and AG 3 isolates were moderately virulent and the $R$. solani AG 4 and binucleate Rhizoctonia AG E isolates were of low virulence at $15^{\circ} \mathrm{C}$.

When inoculum density studies were completed for up to three isolates of each of the Rhizoctonia spp. and AGs, four-parameter sigmoidal models accurately described $68 \%$ of the relationships between the response variable normalized based on the control treatment and log-transformed inoculum densities, whereas $18 \%$ of the relationships were described best with linear models. All three isolates of $R$. solani AG 2-1 and AG 3, two isolates of AG 4, all

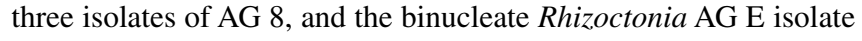

significantly reduced growth of onion seedlings (Table 3; Figs. 13 ). One isolate of AG 4 was nonpathogenic on onion under the cool conditions of this experiment.

Based on significant fits of the models, reductions in onion seedling weight and height were 28 to $63 \%$ for the AG 2-1 isolates, 34 to $63 \%$ for the AG 3 isolates, 15 to $34 \%$ for the AG 4 isolates, 19 to $62 \%$ for the AG 8 isolates, and 44 to $91 \%$ for the AG E isolates. The greatest within-AG variability was observed among the $R$. solani AG 4 isolates, with only isolate Rh070929, which originated from onion roots, causing significant disease responses consistently for all dependent variables of the three AG 4 isolates tested. $R$. solani AG 4 isolate Rh010901 caused significant reductions in onion plant weight and height only, whereas Rh070909 was nonpathogenic on onion. Using virulence as previously defined, $R$. solani AG 8 Rh070943 and the binucleate Rhizoctonia AG E isolate were more virulent on onion than the other pathogenic isolates evaluated under the regime of 13 and $8^{\circ} \mathrm{C}$, day and night, respectively. Of all the pathogenic isolates studied, only $R$. solani AG 8 $\mathrm{Rh} 070943$ consistently had low $\mathrm{ED}_{90}$ estimates for plant weight, plant height, and total root length. $R$. solani AG 8 isolate Rh070927 and AG 3 isolate Rh070933 were highly virulent on onion, having low $\mathrm{ED}_{50}$ estimates and greatly reducing plant growth. $R$. solani AG 4 isolates Rh010901 and Rh070929 as well as $R$. solani AG 3 isolate Rh070942 were of low virulence, whereas all other isolates were of moderate virulence.

All Rhizoctonia spp. studied, except $R$. solani AG 4 and 8, significantly reduced plant emergence as a result of preemergence damping-off compared with that of the noninoculated control plants, and the maximum modeled reductions in emergence were 37 to $100 \%$ (Fig. 4). R. solani AG 2-1 isolates caused a significant $(P=0.0218)$ reduction in emergence, leading to a maximum modeled reduction of $37 \%$ of that of the noninoculated control plants, as well as the smallest derived $\mathrm{ED}_{50}$ estimate of $13.8 \mathrm{CFU} / \mathrm{g}$ of

Table 2. Maximum reduction (Maximum) and the effective inoculum dose which yielded $50 \%$ of the maximum modeled response (ED ${ }_{50}$ ) estimates (lowhigh [mean]) modeled for the combined plant weight, height, and total root length responses of 6-week-old onion seedlings ('Talon') inoculated with Rhizoctonia isolates and grown at $15^{\circ} \mathrm{C}^{\mathrm{a}}$

\begin{tabular}{|c|c|c|c|c|c|}
\hline \multirow[b]{2}{*}{ Species $^{b}$} & \multirow[b]{2}{*}{ Isolate } & \multicolumn{2}{|c|}{ Experiment 1} & \multicolumn{2}{|c|}{ Experiment 2} \\
\hline & & Maximum & $\mathrm{ED}_{50}(\mathrm{CFU} / \mathrm{g}$ of soil $)$ & Maximum & $\mathrm{ED}_{50}(\mathrm{CFU} / \mathrm{g}$ of soil $)$ \\
\hline AG 2-1 & Rh060811 & $24.5-38.6(33.1)$ & $24.0-40.4(32.8)$ & $40.6-41.9(41.1)$ & $3.3-13.8(7.1)$ \\
\hline AG 3 & $\mathrm{Rh} 060801$ & $28.3-65.6(43.2)$ & $77.4-252.1(159.1)$ & $48.6-86.2(64.0)$ & $6.3-93.7(35.8)$ \\
\hline AG 4 & Rh010901 & $28.9-64.4(41.1)$ & $135.2-153.6(145.6)$ & $43.9-79.2(58.8)$ & $28.6-139.6(96.7)$ \\
\hline AG 8 & Rh070927 & $27.9-65.8(42.7)$ & $2.6-3.9(3.2)$ & $38.0-70.5(51.0)$ & $9.3-10.4(9.8)$ \\
\hline AG E & Rh070923 & $30.8-51.3(39.2)$ & $144.8-254.0(192.4)$ & $42.8-81.1(59.1)$ & $47.1-103.0(81.6)$ \\
\hline
\end{tabular}

${ }^{a}$ Data for repeats of the experiment are shown in separate columns. Mean maximum modeled reductions in response variables expressed as $100-$ (percentage of response of noninoculated control plants).

${ }^{\text {b }}$ Rhizoctonia spp. included isolates of $R$. solani anastomosis groups (AGs) 2-1, 3, 4, and 8 as well as a binucleate Rhizoctonia AG E.

Table 3. Maximum reduction (Maximum) and effective inoculum dose which yielded $50 \%$ of the maximum modeled response $\left(E_{50}\right)$ estimates $($ low-high [mean]) modeled for the combined plant weight, height, and total root length responses of 8-week-old onion seedlings ('Talon') inoculated with Rhizoctonia isolates and grown at temperatures of 13 and $8^{\circ} \mathrm{C}$ (day and night, respectively) ${ }^{\mathrm{a}}$

\begin{tabular}{|c|c|c|c|c|c|}
\hline \multirow[b]{2}{*}{ Species, $\mathbf{A G}^{\mathbf{b}}$} & \multirow[b]{2}{*}{ Isolate } & \multicolumn{2}{|c|}{ Experiment 1} & \multicolumn{2}{|c|}{ Experiment 2} \\
\hline & & Maximum & $\mathrm{ED}_{50}(\mathrm{CFU} / \mathrm{g}$ of soil $)$ & Maximum & $\mathrm{ED}_{50}(\mathrm{CFU} / \mathrm{g}$ of soil $)$ \\
\hline \multirow[t]{3}{*}{ AG 2-1 } & Rh060811 & $47.6-48.2(47.9)$ & $5.1-11.0(8.0)$ & $53.6-65.8(60.8)$ & $8.0-43.7(21.8)$ \\
\hline & Rh070913 & $49.3-83.2(60.7)$ & $4.9-28.7(15.0)$ & $36.0-74.0(50.3)$ & $13.4-41.2(24.8)$ \\
\hline & Rh070937 & $47.2-59.2(53.2)$ & $10.6-19.2(14.9)$ & $27.7-40.3(34.0)$ & $13.9-30.8(22.3)$ \\
\hline \multirow[t]{3}{*}{ AG 3} & Rh060801 & $44.1-84.1(61.0)$ & $3.3-20.4$ (10.9) & $38.5-57.3(46.3)$ & $6.0-55.5(28.4)$ \\
\hline & Rh070933 & $50.9-99.8(71.3)$ & $5.2-24.5(12.8)$ & $53.8-75.1(64.0)$ & $7.0-19.0(14.7)$ \\
\hline & Rh070942 & $48.1-74.2(59.2)$ & $13.3-44.4(32.6)$ & $33.7-75.1(51.4)$ & $11.9-67.6(35.7)$ \\
\hline \multirow[t]{3}{*}{ AG 4} & $\mathrm{Rh} 010901$ & $25.7-30.7(28.2)$ & $100.8-153.7(127.3)$ & $17.0-27.5(22.3)$ & $15.4-103.0(59.2)$ \\
\hline & Rh070909 & & & & \\
\hline & Rh070929 & $26.9-34.4(31.1)$ & $3.2-28.7(14.9)$ & $15.4-34.8(28.0)$ & $7.9-24.7(14.8)$ \\
\hline \multirow[t]{3}{*}{ AG 8} & Rh070922 & $18.6-49.7(35.4)$ & $0.8-20.3(8.3)$ & $36.9-69.7(55.8)$ & $2.9-33.0(14.2)$ \\
\hline & Rh070927 & $46.6-90.7(63.1)$ & $10.0-25.6(18.6)$ & $54.9-86.9(70.9)$ & $4.6-6.1(5.4)$ \\
\hline & Rh070943 & $54.8-93.4(70.0)$ & $2.5-5.1(3.9)$ & $42.6-89.8(63.1)$ & $1.9-4.0(3.1)$ \\
\hline AG E & Rh070923 & $44.1-113.9(71.6)$ & $2.9-14.4(7.0)$ & $62.3-114.8(89.2)$ & $4.1-13.8(8.7)$ \\
\hline
\end{tabular}

${ }^{a}$ Data for repeats of the experiment are shown in separate columns. Mean maximum modeled reductions in response variables expressed as $100-$ (percentage of response of noninoculated control plants).

${ }^{\mathrm{b}}$ Rhizoctonia spp. included $R$. solani anastomosis groups (AGs) 2-1,3, 4, and 8 as well as a binucleate Rhizoctonia AG E. 


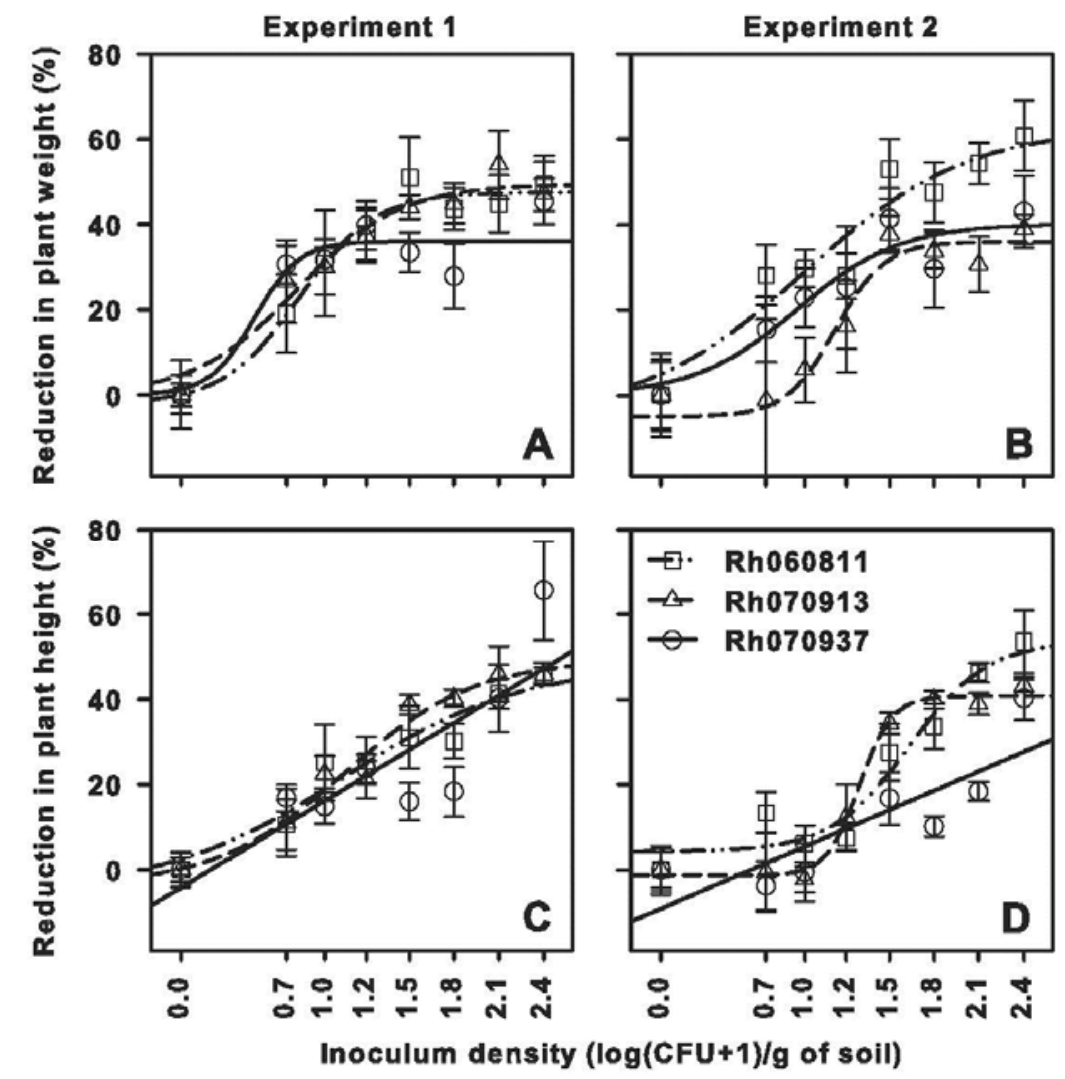

Fig. 1. Effect of inoculum density of Rhizoctonia solani AG 2-1 on the A and B, dry weight, and C and D, height of 8-week-old onion seedlings ('Talon'), expressed as 100 (percentage of the same variable measured for noninoculated control plants). Error bars represent standard errors $(n=10)$. Results of the first experiment are shown in $A$ and $\mathrm{C}$, and results of the repeat experiment in B and D.

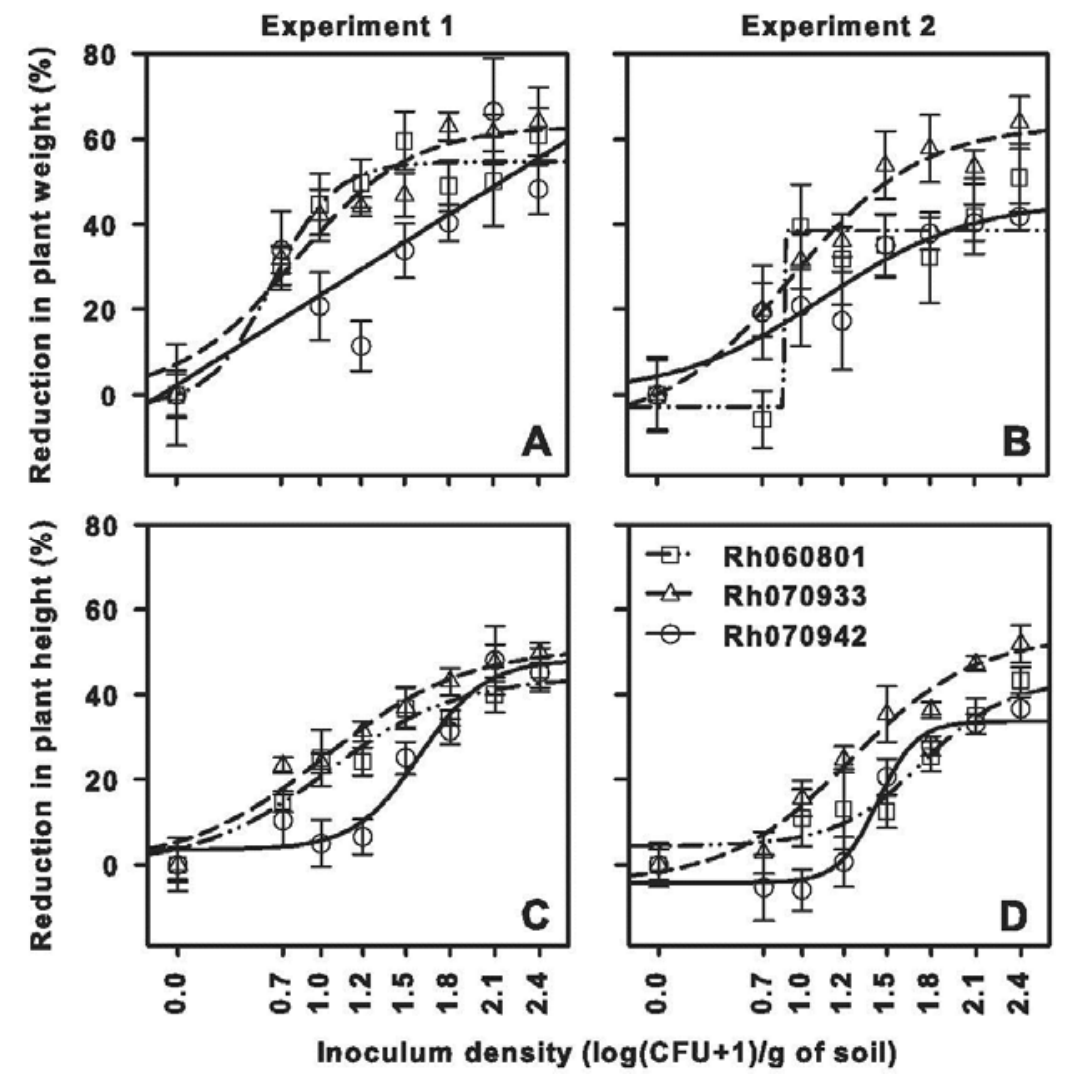

Fig. 2. Effect of inoculum density of Rhizoctonia solani AG 3 on the $\mathbf{A}$ and $\mathbf{B}$, dry weight, and $\mathbf{C}$ and $\mathbf{D}$, height) of 8-week-old onion seedlings ('Talon'), expressed as 100 (percentage of the same variable measured for noninoculated control plants). Error bars represent standard errors $(n=10)$. Results of the first experiment are shown in $A$ and $\mathrm{C}$, and results of the repeat experiment in $\mathrm{B}$ and $\mathrm{D}$. 
soil. $R$. solani AG 3 isolates caused a significant maximum modeled reduction of $42 \%(P=0.0075)$ and an intermediate $\mathrm{ED}_{50}$ estimate of $29.9 \mathrm{CFU} / \mathrm{g}$ of soil. The isolate of binucleate Rhizoctonia spp. AG E caused the most severe preemergence damping-off of the isolates studied, leading to a maximum modeled reduction of $100 \%$ and an $\mathrm{ED}_{50}$ of $34.1 \mathrm{CFU} / \mathrm{g}$ of soil $(P=0.0006)$. In both repeats of the experiment, the AG E isolate completely prevented seedling emergence at the greatest inoculum density $(256 \mathrm{CFU} / \mathrm{g}$ of soil). In the first experiment, there also was no emergence at the second highest inoculum density (128 CFU/g of soil) and only one plant emerged at this inoculum level in the second experiment.

Growth of Rhizoctonia isolates on agar at different temperatures. The colony growth rate response of the Rhizoctonia isolates studied at temperatures of 5 to $35^{\circ} \mathrm{C}$ was best described as a negatively skewed normal distribution with elongated tails at temperatures of 5 to $30^{\circ} \mathrm{C}$ (Fig. 5). Every isolate showed a maximum rate of radial growth from 25 to $30^{\circ} \mathrm{C}$. Only $R$. solani AG 4 isolate $\mathrm{Rh} 070929$ grew more rapidly at 30 than at $25^{\circ} \mathrm{C}(P \leq 0.0001)$, whereas isolates Rh070942 (AG 3), Rh070909 (AG 4), and $\mathrm{Rh} 070918$ (AG 8) each grew as rapidly at 30 as at $25^{\circ} \mathrm{C}$ (Fig. 5). All other isolates grew most rapidly at $25^{\circ} \mathrm{C}$. Averaged across isolates of the same AG at $25^{\circ} \mathrm{C}, R$. solani $\mathrm{AG} 4$ had the fastest maximum growth rate, $34.5 \mathrm{~mm} /$ day, followed by the binucleate $R \mathrm{hi}$ zoctonia AG E isolate at $30.9 \mathrm{~mm} /$ day, $R$. solani $\mathrm{AG} 3$ at 30.6 $\mathrm{mm} /$ day, and $R$. solani AG 8 at $18.8 \mathrm{~mm} /$ day. At this temperature, significant within-AG variation was observed for both AG 3 isolates (26.7 to $33.0 \mathrm{~mm} /$ day) and $\mathrm{AG} 4$ isolates (32.0 to 37.1 $\mathrm{mm}$ /day). However, growth rates for all three AG 8 isolates did not differ significantly. The growth rates exhibited by the three AG 8 isolates from 15 to $30^{\circ} \mathrm{C}$ were nearly half that of the $\mathrm{AG} 3, \mathrm{AG} 4$, and $\mathrm{AG} \mathrm{E}$ isolates.

\section{Discussion}

This is the first published report of the pathogenicity to onion of isolates of Rhizoctonia spp. obtained from the semiarid, irrigated region of onion bulb production in the Columbia Basin of the $\mathrm{Pa}$ cific Northwest region of the United States. Rhizoctonia-induced stunting of onion has recently been identified as a problem by Columbia Basin growers; thus, a limited number of affected fields was available for collecting Rhizoctonia isolates in 2009 and 2010. Even so, a diversity of multinucleate and binucleate Rhizoctonia spp. was detected in the onion soils sampled and isolated directly

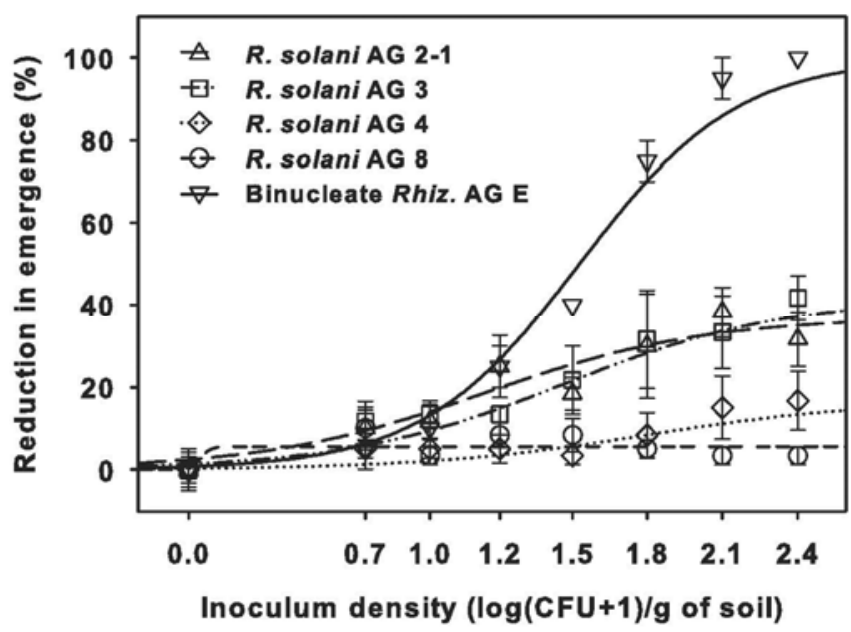

Fig. 4. Effect of inoculum density of Rhizoctonia spp. on emergence of onion seedlings ('Talon'), expressed as 100 - (percentage of emergence of the noninoculated control treatment). A four-parameter, sigmoidal regression analysis was performed on the combined responses for three isolates of each of Rhizoctonia solani AG 2-1 (Rh060811, Rh070913, and Rh070937), R. solani AG 3 (Rh060801, Rh070933, and Rh070942), R. solani AG 4 (Rh010901, Rh070909, and Rh070929), R. solani AG 8 (Rh070922, Rh070927, and Rh070943), and one isolate of binucleate Rhizoctonia AG E (Rh070923) for two repeats of the experiment.

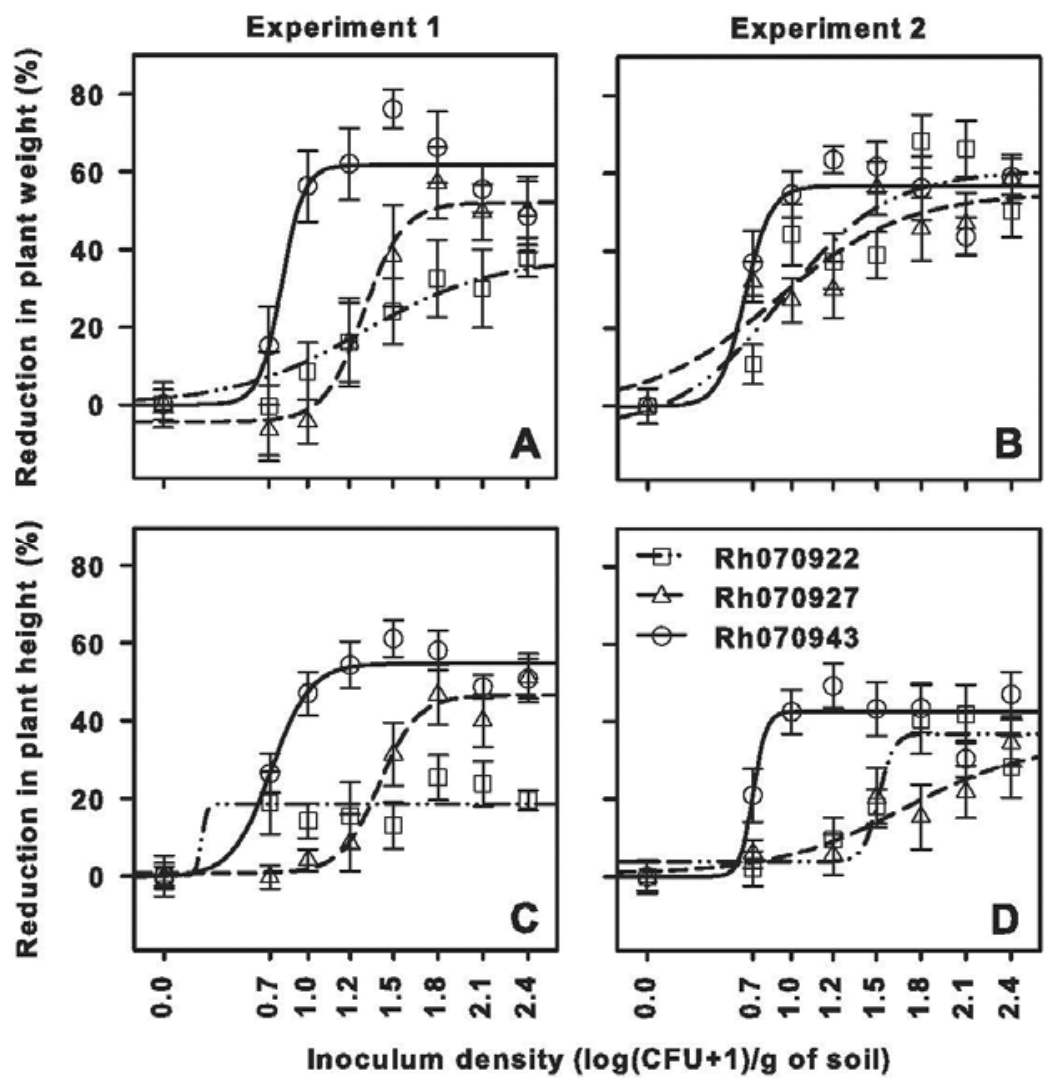

Fig. 3. Effect of inoculum density of Rhizoctonia solani AG 8 on the $\mathbf{A}$ and $\mathbf{B}$, dry weight, and $\mathbf{C}$ and $\mathbf{D}$, height of 8-week-old onion seedlings ('Talon'), expressed as 100 (percentage of the same variable measured for noninoculated control plants). Error bars represent standard errors $(n=10)$. Results of the first experiment are shown in $A$ and $\mathrm{C}$, and results of the repeat experiment in $\mathrm{B}$ and $\mathrm{D}$. 
from plants growing in onion bulb crops, with 11 unique Rhizoctonia groups identified to species and subspecific group. This may reflect the complex cropping sequences of the region, which include many temperate vegetables, graminaceous crops, legumes, and herbs. Diversity of host crops has been correlated with diversity of the Rhizoctonia spp. complex in other vegetable systems in temperate climates $(7,23,31)$. The most dominant isolates obtained in this study were $R$. solani AGs 3, 4, and 8, which is not surprising considering that AG 3 is commonly associated with potato (12), AG 8 with wheat (Triticum aestivum) and barley (Hordeum vulgare) (37), and AG 4 isolates are known to have a wide host range (29). This is the first report of $R$. solani AG 9 isolated from naturally infected pea plants in Oregon, although the AG had previously been collected from soils in wheat and barley fields in the Pacific Northwest $(13,30)$. Isolates of $R$. solani AG 9 are believed not to be pathogenic on pea $(13,55)$, and the pathogenicity of AG 9 isolates on onion was not tested in this study. This is also the first report of binucleate Rhizoctonia AG I isolated from pea in Oregon. This fungal species was recently implicated as a member of the Rhizoctonia complex causing root rot of canola in Washington (39). Also, pathogenicity screenings demonstrated that isolates of AG I can cause stunting of pea (39). Although associations between $R$. solani AG 5 and potato have been observed in Maine (6), North Dakota (11), and other temperate regions $(19,25,53)$, this is the first report of the association in Oregon. $R$. solani AG-5 is implicated as one of the causal agents of Rhizoctonia root rot of apple in the major tree fruit growing areas of central Washington (26).

Isolates of $R$. solani AGs 2-1, 3, 4, and 8; W. circinata var. circinata, and binucleate Rhizoctonia AG E were found consistently to be pathogenic on onion seedlings, although virulence differed among isolates of a species and among species. In all, $82 \%$ of $R h i-$ zoctonia isolates used in this study were obtained from plant roots rather than soil; therefore, it is difficult to determine whether those Rhizoctonia strains isolated directly from roots were more virulent than the isolates baited from bulk soil, as some researchers have observed (56). $R$. solani AG 8 isolates caused severe stunting of onion at the low inoculum densities expected in agricultural soils (47) but did not reduce seedling emergence over a range of temperatures characteristic of the Columbia Basin between February and April, when spring-planted onion crops appear to be most susceptible to infection by Rhizoctonia spp. Wheat and barley are commonly used as winter cover crops in this region, to provide earlyseason wind-break crops in onion bulb fields (16). This finding affirms the possibility that infested graminaceous crops are a primary source of inoculum for onion stunting. $R$. solani AG 8 was also implicated as the main cause of onion stunting in Australia, where wheat and barley are used similarly to protect onion seedlings from wind-blown sand (52). Conversely, Farrokhi-Nejad et al. (19) found that isolates of AG 8 recovered from potato tubers in New Zealand caused the lowest disease severity on onion of the Rhizoctonia spp. studied.

The $R$. solani AG 8 isolate collected from onion ( $\mathrm{Rh} 070927)$ caused up to 1.7 times greater reduction in plant growth (average of plant weight, height, and total root length) at 13 and $8^{\circ} \mathrm{C}$ day and night temperatures, respectively, than at 15 and $15^{\circ} \mathrm{C}$, although symptoms developed at lower inoculum densities at the warmer temperature regime. At the lower temperature regime, $R$. solani AG 8 isolate Rh070943 collected from pea plants was markedly more virulent than the other two AG 8 isolates studied, causing severe reductions in plant weight at low inoculum densities. Seemingly rare in agricultural soils of the Pacific Northwest, one isolate of binucleate Rhizoctonia AG E, a species previously observed to be either weakly virulent $(8,19)$ or avirulent $(46)$, was highly virulent at 13 and $8^{\circ} \mathrm{C}$ but caused limited disease at 15 and $15^{\circ} \mathrm{C}$. The AG E isolate also significantly reduced onion emergence, leading to complete preemergence damping-off at high inoculum densities. In contrast, preemergence damping-off was not a symptom observed under field conditions. The finding that $R$. solani AG 2-1 and AG 3 isolates were mostly of moderate virulence on onion is consistent with other studies $(19,52)$. In this study, however, one AG 3 isolate (Rh070933) was highly virulent at the cooler temperatures whereas, at the warmer temperatures, another $R$. solani AG 3 isolate (Rh060801) caused the most severe onion stunting of the isolates tested. This is the first published finding that $R$. solani AG 2-1 and AG 3 isolates can cause substantial reductions in onion emergence: 37 and $42 \%$, respectively. Two AG 4 isolates were of low virulence and one isolate was nonpathogenic on onion at the cooler temperature regime. Some researchers also have observed considerable variability in disease response to isolates of this $\mathrm{AG}$ $(22,23,52)$ while other researchers have not $(18,19)$.

The isolates of binucleate Rhizoctonia AG A and AG I evaluated in this study were nonpathogenic on onion. However, both isolates significantly stimulated plant growth across a range of inoculum densities. To our knowledge, AG I isolates have not been studied on onion previously. It is possible that significant within-AG variation exists among isolates of AG A, because Juan-Abgona et al. (23) found significantly different levels of virulence, ranging from low to moderate. On the other hand, Burpee et al. (8), IchielevichAuster et al. (22), and Sumner et al. (46) demonstrated that 14 isolates of AG A among these three studies were all nonpathogenic to onion. An isolate of W. circinata var. circinata evaluated in this study was weakly virulent on onion, causing limited reductions in plant growth (21 to $22 \%$ reduction in biomass) at high inoculum densities. Although isolates of $W$. circinata var. zeae can be moderately virulent on onion $(18,22)$, this appears to be the first report on the virulence of $W$. circinata var. circinata on onion. An isolate of $R$. solani AG 5 did not cause significant reductions in onion plant biomass and had an inconsistent impact on other plant responses. In other studies, however, AG 5 isolates have caused moderate levels (19) or no disease (22) on onion.

Consistent with the literature $(11,25)$, relative growth rate of Rhizoctonia isolates was not correlated positively with virulence on onion within an AG. At 5 to $15^{\circ} \mathrm{C}$, which covered the temperature range used in the pathogenicity experiments, $R$. solani AG 3 Rh070933 grew significantly slower than the other two AG 3 isolates but caused the most severe onion stunting. Similarly, of the $R$. solani AG 8 isolates studied, Rh070922 grew significantly faster than $\mathrm{Rh} 070943$ at 5 to $15^{\circ} \mathrm{C}$ but, nonetheless, isolate Rh070943 caused substantially greater reductions in onion growth. Isolate $\mathrm{Rh} 070909$ grew fastest at 10 to $15^{\circ} \mathrm{C}$ of the three $R$. solani AG 4 isolates studied but was not pathogenic on onion, whereas the slowest-growing isolate, Rh070929, consistently caused disease at 13 and $8^{\circ} \mathrm{C}$ day and night temperatures. Some of the isolates used in the pathogenicity studies at both 13 and $8^{\circ} \mathrm{C}$ (day and night) and

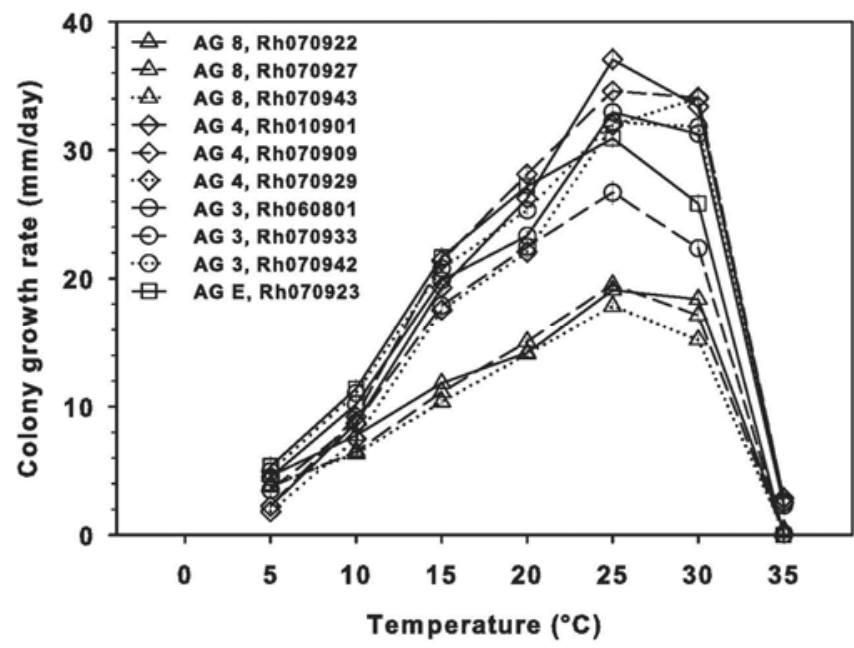

Fig. 5. Radial colony growth rate (mm/day) of Rhizoctonia solani AG 3 (Rh060801, Rh070933, and Rh070942), R. solani AG 4 (Rh010901, Rh070909, and Rh070929), R. solani AG 8 (Rh070922, Rh070927, and Rh070943), and a binucleate Rhizoctonia AG E (Rh070923) on 1/5-strength potato dextrose agar at temperatures of 5 to $35^{\circ} \mathrm{C}$. Each data point is the mean of eight replications. 
15 and $15^{\circ} \mathrm{C}$ (day and night) were more virulent at the cooler temperature regime, which is interesting considering that all isolates grew significantly faster at 15 than at 8 to $13^{\circ} \mathrm{C}$. For instance, $R$. solani AG 8 isolate Rh070927 reduced onion growth almost two-fold more (based on an average of plant weight, height, and total root length) at the cooler versus higher temperature regimes.

In summary, stunting of onion plants at temperatures of 8 to $15^{\circ} \mathrm{C}$ in fine sandy loam field soil was caused by isolates of $R$. solani AGs 2-1, 3, 4, and 8; W. circinata var. circinata; and binucleate Rhizoctonia AG E. Only $R$. solani AG 8 isolates, however, consistently caused severe symptoms at low inoculum densities. This suggests the existence of a host bridge between wheat and barley cover crops that are commonly infected with AG 8 isolates and dry bulb onion crops. To maintain healthy onion crops, growers might consider cultivating nonhost winter cover crops in rotation or increasing the interval between the selective killing of the cereal cover crop and planting onion crops $(3,41)$. One $R$. solani AG 3 isolate was highly virulent and two were moderately virulent on onion. Therefore, growing potato in rotation with onion crops, or the presence of volunteer potato plants in onion crops, might also make for a host bridge to onion. $R$. solani AG 2-1 isolates were moderately virulent on onion and AG 4 isolates caused low levels of disease, as did the $W$. circinata var. circinata isolate. $R$. solani AG 2-1 and AG 3 as well as binucleate Rhizoctonia AG E isolates significantly reduced onion emergence but $R$. solani isolates of AG 4 and AG 8 did not. This study was limited by the small number of stunted onion crops sampled when the problem was first detected. The disease has since been documented across the Columbia Basin onion production region (17). Because significant within-AG variation in virulence was observed for Rhizoctonia spp. pathogenic on onion, there is a need to test the virulence of a greater number of isolates collected from a larger production region. Additionally, different crop management practices should be investigated further, including the use of different fungicide chemistries (42) and the optimum duration between herbicide application to the cereal cover crop and planting onion (41).

\section{Acknowledgments}

This project was supported, in part, by the Washington State University Agricultural Research Center and the College of Agricultural, Human, and Natural Resource Sciences. We thank M. Evans for help with data analysis, K. Schroeder for research support, and the grower-cooperators in the Columbia Basin for their support and cooperation in this project.

\section{Literature Cited}

1. Andersen, T. F., and Stalpers, J. A. 1994. A check-list of Rhizoctonia epithets. Mycotaxon 51:437-457.

2. Anderson, N. A. 1982. The genetics and pathology of Rhizoctonia solani. Annu. Rev. Phytopathol. 20:329-347.

3. Babiker, E. M., Hulbert, S. H., Schroeder, K. L., and Paulitz, T. C. 2011. Optimum timing of preplant applications of glyphosate to manage Rhizoctonia root rot in barley. Plant Dis. 95:304-310.

4. Baker, R. 1971. Analyses involving inoculum density of soil-borne plant pathogens in epidemiology. Phytopathology 61:1280-1292.

5. Bakkeren, G., Kronstad, J. W., and Lévesque, C. A. 2000. Comparison of AFLP fingerprints and ITS sequences as phylogenetic markers in Ustilaginomycetes. Mycologia 92:510-521.

6. Bandy, B. P., Leach, S. S., and Tavantzis, S. M. 1988. Anastomosis Group 3 is the major cause of Rhizoctonia disease of potato in Maine. Plant Dis. 72:596-598.

7. Budge, G. E., Shaw, M. W., Lambourne, C., Jennings, P., Clayburn, R., Boonham, N., and McPherson, M. 2009. Characterization and origin of infection of Rhizoctonia solani associated with Brassica oleracea crops in the UK. Plant Pathol. 58:1059-1070.

8. Burpee, L., Sanders, P. L., Cole, H., and Sherwood, R. T. 1980. Pathogenicity of Ceratobasidium cornigerum and related fungi representing five anastomosis groups. Phytopathology 70:843-846.

9. Carling, D. E. 1996. Grouping of Rhizoctonia solani by hyphal anastomosis reactions. Pages 37-47 in: Rhizoctonia Species: Taxonomy, Molecular Biology, Ecology, Pathology and Disease Control. Kluwer Academic Publishers, Dordrecht, The Netherlands.

10. Carling, D. E., Baird, R. E., Gitaitis, R. D., Brainard, K. A., and Kuninaga, S. 2002. Characterization of AG-13, a newly reported anastomosis group of Rhizoctonia solani. Phytopathology 92:893-899.
11. Carling, D. E., Kebler, K. M., and Leiner, R. H. 1986. Interactions between Rhizoctonia solani AG-3 and 27 plant species. Plant Dis. 70:577-578.

12. Carling, D. E., and Leiner, R. H. 1990. Virulence of isolates of Rhizoctonia solani AG-3 collected from potato plant organs and soil. Plant Dis. 74:901903.

13. Carling, D. E., Leiner, R. H., and Kebler, K. M. 1987. Characterization of a new anastomosis group (AG-9) of Rhizoctonia solani. Phytopathology 77:1609-1612.

14. Carling, D. E., Pope, E. J., Brainard, K. A., and Carter, D. A. 1999. Characterization of mycorrhizal isolates of Rhizoctonia solani from an orchid, including AG-12, a new anastomosis group. Phytopathology 89:942-946.

15. De Candolle, A. P. 1815. Mémoire sur les rhizoctones, nouveau genre de champignons qui attaque les racines, des plantes et en particulier celle de la luzerne cultivée, 2nd ed. Memoires du Museum Nationale D'Histoire Naturelle, Paris.

16. du Toit, L. J. 2009. Rhizoctonia seedling blight of onion in the Columbia Basin. 2009 Washington State University Onion Field Day, Quincy.

17. du Toit, L. J., Poudyal, D. S., Paulitz, T., Porter, L., Eggers, J., and Hamm, P. 2012. Onion stunting caused by Rhizoctonia: management and economic importance in the Columbia Basin of Oregon and Washington. Pages 68-77 in: Proc. 2012 Nat. Allium Res. Conf. Las Cruces, NM. http://aces.nmsu. edu/narc2012/index.html

18. Erper, I., Karaca, G. H., Turkkan, M., and Ozkoc, I. 2006. Characterization and pathogenicity of Rhizoctonia spp. from onion in Amasya, Turkey. Phytopathology 154:75-79.

19. Farrokhi-Nejad, R., Cromey, M. G., and Moosawi-Jorf, S. A. 2007. Determination of the anastomosis grouping and virulence of Rhizoctonia spp. associated with potato tubers grown in Lincoln, New Zealand. Pak. J. Biol. Sci. 10:3786-3793.

20. Garcia, V. G., Onco, M. A. P., and Susan, V. R. 2006. Biology and systematics of the form genus Rhizoctonia. Span. J. Agric. Res. 4:55-79.

21. Hjortstam, K., and Larsson, K. H. 1998. A checklist to genera and species of corticioid fungi (Basidiomycotina, Aphyllophorales). Windahlia 23:1-53.

22. Ichielevich-Auster, M., Sneh, B., Koltin, Y., and Barash, I. 1985. Pathogenicity, host specificity and anastomosis groups of Rhizoctonia spp. isolated from soils in Israel. Phytoparasitica 13:103-112.

23. Juan-Abgona, R., Katsuno, N., Kageyama, K., and Hyakumachi, M. 1996. Isolation and identification of hypovirulent Rhizoctonia spp. from soil. Plant Pathol. 45:896-904.

24. Kuninaga, S., Natusaki, T., Takeuchi, T., and Yokosawa, R. 1997. Sequence variation of the rDNA ITS regions within and between anastomosis groups in Rhizoctonia solani. Curr. Genet. 32:237-243.

25. Lehtonen, M. J., Ahvenniemi, P., Wilson, P. S., German-Kinnari, M., and Valkonen, J. P. T. 2008. Biological diversity of Rhizoctonia solani (AG-3) in a northern potato-cultivation environment in Finland. Plant Pathol. 57:141151.

26. Mazzola, M. 1998. Elucidation of the microbial complex having a causal role in the development of apple replant disease in Washington. Phytopathology 88:930-938.

27. Mazzola, M., Smiley, R. W., Rovira, A. D., and Cook, J. R. 1996. Characterization of Rhizoctonia isolates, disease occurrence and management in cereals. Pages 259-267 in: Rhizoctonia Species: Taxonomy, Molecular Biology, Ecology, Pathology and Disease Control. Kluwer Academic Publishers, Dordrecht, The Netherlands.

28. National Oceanic and Atmospheric Administration, National Climatic Data Center. http://www.ncdc.noaa.gov

29. Ogoshi, A. 1987. Ecology and pathogenicity of anastomosis and intraspecific groups of Rhizoctonia solani Kühn. Annu. Rev. Phytopathol. 25:125143.

30. Ogoshi, A., Cook, R. J., and Bassett, E. N. 1990. Rhizoctonia species and anastomosis groups causing root rot of wheat and barley in the Pacific Northwest. Phytopathology 80:784-788.

31. Ohkura, M., Abawi, G. S., Smart, C. D., and Hodge, K. T. 2009. Diversity and aggressiveness of Rhizoctonia solani and Rhizoctonia-like fungi on vegetables in New York. Plant Dis. 93:615-624.

32. Parmeter, J. R., Jr., and Whitney, H. S. 1970. Taxonomy and nomenclature of the imperfect state. Pages 7-19 in: Rhizoctonia solani: Biology and $\mathrm{Pa}-$ thology. University of California Press, Berkeley.

33. Paulitz, T. C., and Schroeder, K. L. 2005. A new method for the quantification of Rhizoctonia solani and R. oryzae from soil. Plant Dis. 89:767-772.

34. Paulitz, T. C., Smiley, R. W., and Cook, R. J. 2002. Insights into the prevalence and management of soilborne cereal pathogens under direct seeding in the Pacific Northwest, U.S.A. Can. J. Plant Pathol. 24:416-428.

35. Paulitz, T. C., Zhang, H., and Cook, R. J. 2001. Spatial distribution of Rhizoctonia root rot in direct-seeded barley. (Abstr.) Phytopathology 91:S70.

36. Pelter, G. Q., and Sorensen, E. J. 2003. Crop profile for onions in Washington. Regional Integrated Pest Management Centers, United States Department of Agriculture.

37. Pumphrey, F. V., Wilkins, D. E., Hane, D. C., and Smiley, R. W. 1987. Influence of tillage and nitrogen fertilizer on Rhizoctonia root rot (bare patch) of winter wheat. Plant Dis. 71:125-127.

38. Schroeder, K. L., Okubara, P. A., Tambong, J. T., and Paulitz, T. C. 2006. Identification and quantification of pathogenic Pythium spp. from soils in eastern Washington using real-time polymerase chain reaction. Phytopathol- 
ogy 96:637-647.

39. Schroeder, K., and Paulitz, T. C. 2012. First report of Ceratobasidium sp. causing root rot on canola in Washington State. Plant Dis. 96:591.

40. Schwartz, H. F., and Mohan, S. K. 2008. Compendium of Onion and Garlic Diseases, 2nd ed. American Phytopathological Society, St. Paul, MN.

41. Sharma-Poudyal, D., Paulitz, T., Porter, L., Eggers, J., Hamm, P., and du Toit, L. J. 2013. Effect of timing of glyphosate application to a winter cover crop on stunting of spring-sown onions caused by Rhizoctonia spp. in the Columbia Basin of Washington, 2012. Plant Dis. Manage. Rep. 7:V046.

42. Sharma-Poudyal, D., Paulitz, T., Porter, L., Eggers, J., Hamm, P., and du Toit, L. J. 2013. Efficacy of fungicides to manage onion stunting caused by Rhizoctonia spp. in the Columbia Basin of Oregon and Washington, 20112012. Plant Dis. Manage. Rep. 7:V047.

43. Sharma-Poudyal, D., Paulitz, T., Porter, L., Eggers, J., Hamm, P., and du Toit, L. J. 2013. Yield responses of three onion cultivars to stunting caused by Rhizoctonia spp. in the Columbia Basin of Oregon and Washington, 2012. Plant Dis. Manage. Rep. 7:V048.

44. Smiley, R. W., and Uddin, W. 1993. Influence of soil temperature on Rhizoctonia root rot ( $R$. solani AG-8 and $R$. oryzae) of winter wheat. Phytopathology 83:777-785.

45. Spiess, A. N., and Neumeyer, N. 2010. An evaluation of $r^{2}$ as an inadequate measure for nonlinear models in pharmacological and biochemical research: a Monte Carlo approach. BMC Pharmacol. 10:1-11.

46. Sumner, D. R., Gitaitis, R. D., Gay, J. D., Smittle, D. A., Maw, B. W., Tollner, E. W., and Hung, Y. C. 1997. Control of soilborne pathogenic fungi in fields of sweet onion. Plant Dis. 81:885-891.

47. Sumner, D. R., Phatak, S. C., Gay, J. D., Chalfant, R. B., Brunson, K. E., and Bugg, R. L. 1995. Soilborne pathogens in a vegetable double-crop with conservation tillage following winter cover crops. Crop Prot. 14:495-500.

48. Sweetingham, M. W., Cruickshank, R. H., and Wong, D. H. 1986. Pectic zymogram and taxonomy, and pathogenicity of the Ceratobasidiaceae. Trans. Br. Mycol. Soc. 86:305-311.

49. United States Department of Agriculture, National Agricultural Statistics Service. Vegetables 2011 summary. Tech. Rep. January 2012.

50. Weinhold, A. R., and Sinclair, J. B. 1996. Rhizoctonia solani: penetration, colonization, and host response. Pages 163-174 in: Rhizoctonia Species: Taxonomy, Molecular Biology, Ecology, Pathology and Disease Control. Kluwer Academic Publishers, Dordrecht, The Netherlands.

51. Weller, D. M., Cook, R. J., MacNish, G., Bassett, E. N., Powelson, R. L., and Petersen, R. R. 1986. Rhizoctonia root rot of small grains favored by reduced tillage in the Pacific Northwest. Plant Dis. 70:70-73.

52. Wicks, T., Walker, G., Pederick, S., and Anstis, S. 2010. Onion stunting in South Australia associated with Rhizoctonia solani AG 8. Australas. Plant Pathol. 40:126-132.

53. Woodhall, J. W., Lees, A. K., Edwards, S. G., and Jenkinson, P. 2007. Characterization of Rhizoctonia solani from potato in Great Britain. Plan Pathol. 56:286-295.

54. Yamamoto, D. T., and Uehara, H. 1972. Seedling damping-off of welsh onion and the control. Plant Prot. 26:153-159.

55. Yang, J., Kharbanda, P. D., Wang, H., and McAndrew, D. W. 1996. Characterization, virulence, and genetic variation of Rhizoctonia solani AG-9 in Alberta. Plant Dis. 80:513-518.

56. Yitbarek, S. M., Verma, P. R., and Morrall, R. A. A. 1987. Anastomosis groups, pathogenicity, and specificity of Rhizoctonia solani isolates from seedling and adult rapeseed/canola plants and soils in Saskatchewan. Can. J. Plant Pathol. 9:6-13. 